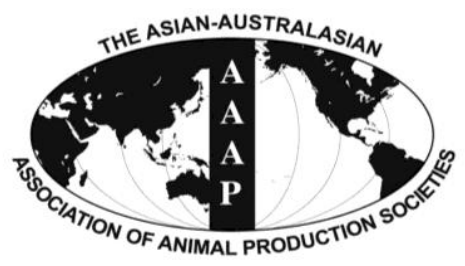

Asian-Aust. J. Anim. Sci.

Vol. 25, No. $10: 1374$ - 1380

October 2012

www.ajas.info

http://dx.doi.org/10.5713/ajas.2012.12084

\title{
Effects of Maturity Stages on the Nutritive Composition and Silage Quality of Whole Crop Wheat
}

\author{
Z. L. Xie, T. F. Zhang, X. Z. Chen, G. D. Li and J. G. Zhang* \\ Department of Grassland Science, South China Agricultural University, Guangzhou, China
}

\begin{abstract}
The changes in yields and nutritive composition of whole crop wheat (Triticum aestivum L.) during maturation and effects of maturity stage and lactic acid bacteria (LAB) inoculants on the fermentation quality and aerobic stability were investigated under laboratory conditions. Whole crop wheat harvested at three maturation stages: flowering stage, milk stage and dough stage. Two strains of LAB (Lactobacillus plantarum: LAB1, Lactobacillus parafarraqinis: LAB2) were inoculated for wheat ensiling at $1.0 \times 10^{5}$ colony forming units per gram of fresh forage. The results indicated that wheat had higher dry matter yields at the milk and dough stages. The highest water-soluble carbohydrates content, crude protein yields and relative feed value of wheat were obtained at the milk stage, while contents of crude fiber, neutral detergent fiber and acid detergent fiber were the lowest, compared to the flowering and dough stages. Lactic acid contents of wheat silage significantly decreased with maturity. Inoculating homofermentative LAB1 markedly reduced $\mathrm{pH}$ values and ammonia-nitrogen $\left(\mathrm{NH}_{3}-\mathrm{N}\right)$ content $(\mathrm{p}<0.05)$ of silages at three maturity stages compared with their corresponding controls. Inoculating heterofermentative LAB2 did not significantly influence $\mathrm{pH}$ values, whereas it notably lowered lactic acid and $\mathrm{NH}_{3}-\mathrm{N}$ content $(\mathrm{p}<0.05)$ and effectively improved the aerobic stability of silages. In conclusion, considering both yields and nutritive value, whole crop wheat as forage should be harvested at the milk stage. Inoculating LAB1 improved the fermentation quality, while inoculating LAB2 enhanced the aerobic stability of wheat silages at different maturity stages. (Key Words: Whole Crop Wheat, Maturity, Lactic Acid Bacteria, Fermentation Quality, Aerobic Stability)
\end{abstract}

\section{INTRODUCTION}

Wheat (Triticum aestivum L.), a major cereal crop, is widely cultured in many parts of the world. In the past few years, great attention has been paid to its feeding value due to a shortage of roughage. Whole crop wheat can serve as an excellent forage crop for high-lactating cows or beef cattle in terms of its digestible fibers and energy, and its nutritional value may approach that of maize silage (Adamson et al., 1992). Therefore, whole crop wheat has been widely used for ensiling in Israel, Turkey and some areas of the United States due to its strong adaptability and high feeding value.

In China, wheat is mainly cultivated in the northern regions as food crop, but its use as silage has been rarely reported. In addition, the fields in southern China are fallow in winter over five months after rice (Oryza sativa L.) harvest, which causes enormous economic losses and waste of land resources and energies (Zhang et al., 2008). Wheat

\footnotetext{
* Corresponding Author: J. G. Zhang. Tel: +86-20-38604789, Fax: +86-20-38604789, E-mail: zhangjg@scau.edu.cn Submitted Feb. 13, 2012; Accepted May 15, 2012; Revised Jun. 24, 2012
}

can be grown as a kind of cover crop in winter and harvested in the following spring, thereafter the land is cleared for summer crops (Ashbell et al., 1985; Filya, 2003b). Therefore, planting wheat in winter fallow fields, is not only beneficial to improve the utilization of paddy fields, but also provides a great amount of forage to animals. However, the maturation stage is vital to the nutritive value and ensiling process of whole crop wheat (Filya, 2003b). Arieli and Adin (1994) reported that wheat harvested at flowering stage for silage was superior to other maturity stages by studying the NDF digestibility and milk yields of lactating cows. However, Ashbell et al. (1997) and Weinberg et al. (1991, 1993b) found that the best time for wheat silage making was the milk stage, in terms of the yields, nutrient composition and fermentation quality. Therefore, it remains unclear which is the best stage of maturity to harvest whole crop wheat for ensiling.

Ensiling is a common preservation method for moist forage crops. It is based on anaerobic fermentation, where epiphytic lactic acid bacteria (LAB) convert water-soluble carbohydrates (WSC) into organic acids, mainly lactic acid (McDonald et al., 1991; Weinberg et al., 2010). As a result, 
a low $\mathrm{pH}$ value inhibits the undesirable microorganisms and the forage crop is preserved. In order to improve the efficiency of silage fermentation, various chemical and biological additives have been used in silage processing. The biological additives, LAB inoculants in particular, are advantageous and regarded as natural products because they are safe, easy to use and environmentally friendly (Filya et al., 2000). LAB inoculants are added to silage to stimulate lactic acid fermentation and decrease $\mathrm{pH}$ and thus improve the fermentation quality. Many studies have indicated such advantages of homofermentative LAB inoculants (Weinberg et al., 1988; Henderson et al., 1990; Spoelstra, 1991). However, such inoculants have also occasionally been shown to impair the aerobic stability of silage. Weinberg et al. (1993a, b) reported that mature cereal crops silages with homofermentative $\mathrm{LAB}$ inoculants were susceptible to spoilage.

The purpose of the present experiment was to study the changes of yield and nutritive composition during wheat maturation, and to research the effects of the maturity stage and LAB inoculants on the fermentation quality and aerobic stability of whole crop wheat silage.

\section{MATERIALS AND METHODS}

\section{Wheat seeding and management}

Wheat variety Ningmai 13 was grown on the experimental field at the College of Agriculture, South China Agricultural University (Guangzhou, China) in triplicate plots $3.0 \mathrm{~m} \times 4.0 \mathrm{~m}$. The crop was sown on Dec 10 , 2010 after the late rice was harvested. Seeding rate was 180 $\mathrm{kg} / \mathrm{ha}$. Before sowing, $45.0 \mathrm{~kg} / \mathrm{ha}$ nitrogen, $18.0 \mathrm{~kg} / \mathrm{ha} \mathrm{P}_{2} \mathrm{O}_{5}$ and $24.0 \mathrm{~kg} / \mathrm{ha} \mathrm{K}_{2} \mathrm{O}$ was uniformly applied. Immediately prior to booting in spring, $67.5 \mathrm{~kg} / \mathrm{ha}$ nitrogen, $27.0 \mathrm{~kg} / \mathrm{ha}$ $\mathrm{P}_{2} \mathrm{O}_{5}$ and $36.0 \mathrm{~kg} / \mathrm{ha} \mathrm{K}_{2} \mathrm{O}$ was broadcasted. Wheat was harvested at three maturation stages: flowering (Mar 12, 2011), milk (Mar 31, 2011) and dough stage (Apr 13, 2011), respectively. The yields obtained at each stage were determined by weighing the forage harvested from a quadrant of $1.0 \mathrm{~m} \times 1.0 \mathrm{~m}$ in triplicates and calculating the average. The analysis samples and ensiling materials were taken, respectively.

\section{Silage making}

Wheat materials were chopped into 2 to $3 \mathrm{~cm}$ lengths by a forage chopper, after thorough mixing, samples were taken for analyses of chemical composition and microorganisms. The materials were inoculated with two strains of LAB (Lactobacillus plantarum: LAB1, Lactobacillus parafarraqinis: LAB2, both were isolated by our laboratory) at $1.0 \times 10^{5}$ colony forming units per gram of fresh matter (cfu/g FM) and the control was sprayed with the same amount of distilled water alone. After treating and thorough mixing, $200 \mathrm{~g}$ of wheat material was filled into a plastic film bag $(30 \mathrm{~cm} \times 20 \mathrm{~cm}$, Mingkang Packing Co. Ltd, Zhongshan, China) in triplicate, degassed and sealed using a vacuum sealer (SINBO Vacuum Sealer, Hong Tai Home Electrical Appliance Co. Ltd, Hongkong, China). Thereafter, they were kept in the dark at ambient temperature for $60 \mathrm{~d}$.

\section{Microbial and chemical analyses}

Ten $\mathrm{g}$ of each silage material was shaken well with 90 $\mathrm{ml}$ of sterilized saline solution $(0.85 \% \mathrm{NaCl})$, and serial dilutions $\left(10^{-1}\right.$ to $\left.10^{-6}\right)$ were made in sterile saline solution. LAB were counted on de Man, Rogosa and Sharp (MRS) medium agar (Difco Laboratories, Detroit, MI, USA) after incubation in an anaerobic incubator $\left(\mathrm{N}_{2}: \mathrm{H}_{2}: \mathrm{CO}_{2}=85: 5: 10\right.$, YQX-II, CIMO Medical Instrument Manufacturing Co., Ltd, Shanghai, China) at $37^{\circ} \mathrm{C}$ for $3 \mathrm{~d}$. Aerobic bacteria were counted on nutrient agar (Nissui-seiyaku Ltd, Tokyo, Japan), yeasts and mold were counted on potato dextrose agar (Nissui-seiyaku Ltd) acidified with sterilized tartaric acid solution to $\mathrm{pH} 3.5$. The agar plates were incubated at $37^{\circ} \mathrm{C}$ for $3 \mathrm{~d}$.

The buffering capacity of wheat was determined as described by Playne and McDonald (1966). A $20 \mathrm{~g}$ sample was taken, mixed with $80 \mathrm{ml}$ of distilled water and stored in a refrigerator at $4^{\circ} \mathrm{C}$ for $18 \mathrm{~h}$. Then, the material was filtered and $\mathrm{pH}$ was determined on the filtrate with a glass electrode $\mathrm{pH}$ meter (PHS-3C, CSDIHO Co., Ltd, Shanghai, China). Dry matter (DM) content was determined by oven drying at $70^{\circ} \mathrm{C}$ for $48 \mathrm{~h}$. Crude fiber, neutral detergent fiber (NDF) and acid detergent fiber (ADF) contents were measured according to the procedures of Van Soest et al. (1991). Crude ash contents were measured after incinerated for $3 \mathrm{~h}$ at $550^{\circ} \mathrm{C}$. WSC contents were determined using the anthrone method (Murphy, 1958). Crude protein (CP) and ether extract were analyzed according to AOAC methods (1990).

When the bag silos were opened after ensiling for $60 \mathrm{~d}$, the silage was mixed thoroughly. The $\mathrm{pH}$ values were measured according to the same method for the fresh wheat. Concentration of ammonia-nitrogen $\left(\mathrm{NH}_{3}-\mathrm{N}\right)$ was analyzed using the indophenols blue method (Novozamsky et al., 1974). The organic acid contents were analyzed by high performance liquid chromatography (column: Sodex RS Pak KC-811, Showa Denko K.K., Kawasaki, Japan; detector: DAD, $210 \mathrm{~nm}$, SPD-20A, Shimadzu Co., Ltd, Kyoto, Japan; eluent: $3 \mathrm{mmol} / \mathrm{L} \mathrm{HClO}_{4}, 1.0 \mathrm{ml} / \mathrm{min}$; temperature: $60^{\circ} \mathrm{C}$ ).

The aerobic stability was studied by putting silage materials in insulated polystyrene foam boxes at ambient temperature and covering with gauze to allow air to enter. The $\mathrm{pH}$ changes of silages were measured at 48, 96, 144 and $192 \mathrm{~h}$, respectively.

$V$-score, which was used to assess the silage 
fermentation quality, was determined from the proportion $\mathrm{NH}_{3}-\mathrm{N}$ in the total nitrogen (TN) and volatile fatty acid (VFA) contents in the silage (Association of Self-supply Feed Evaluation, 2001).

\section{Relative feed value}

Relative feed value (RFV) is a widely accepted forage quality index in the marketing of hays in the United States and has become a common tool for determining hay quality (intake and energy value). It was developed by the Hay Marketing Task Force of the American Forage and Grassland Council (Rohweder et al., 1978). RFV is calculated from estimation of ADF and NDF. The formula for calculating RFV is:

$$
\mathrm{DDM}(\% \mathrm{DM})=88.9-0.779 \times \mathrm{ADF}(\% \mathrm{DM})
$$

DMI $(\%$ Body weight $)=120 / \mathrm{NDF}(\% \mathrm{DM})$

$$
\mathrm{RFV}=(\mathrm{DDM} \times \mathrm{DMI}) / 1.29
$$

Where $\mathrm{DDM}=$ dry matter digestibility, DMI = dry matter intake, $\mathrm{NDF}=$ neutral detergent fiber, $\mathrm{ADF}=$ acid detergent fiber, $\mathrm{RFV}=$ relative feed value.

\section{Statistical analysis}

Data of chemical and microbial composition of wheat prior to ensiling were subjected to one-way analysis of variance and data of silage fermentation were analyzed by two-way analysis of variance to evaluate the effects of growth stage, LAB inoculants and their interaction on the items of fermentation quality. The means were then compared for significance by Duncan's multiple range
Table 1. The yields and RFV of wheat at three maturity stages

\begin{tabular}{lllr}
\hline Maturity stage & \multicolumn{1}{c}{$\begin{array}{c}\text { DM yields } \\
(\mathrm{t} / \mathrm{ha})\end{array}$} & $\begin{array}{c}\text { CP yields } \\
(\mathrm{t} / \mathrm{ha})\end{array}$ & \multicolumn{1}{c}{ RFV } \\
\hline Flowering & $4.67 \pm 0.11^{\mathrm{b}}$ & $0.51 \pm 0.03^{\mathrm{b}}$ & $93.60 \pm 3.98^{\mathrm{b}}$ \\
Milk & $7.59 \pm 0.43^{\mathrm{a}}$ & $0.71 \pm 0.05^{\mathrm{a}}$ & $131.56 \pm 1.07^{\mathrm{a}}$ \\
Dough & $7.73 \pm 0.30^{\mathrm{a}}$ & $0.50 \pm 0.02^{\mathrm{b}}$ & $102.88 \pm 2.11^{\mathrm{b}}$ \\
SEM & 0.18 & 0.02 & 2.64 \\
\hline
\end{tabular}

Average means \pm standard deviations.

Values within the same column with different letters differ significantly from each other at $\mathrm{p}<0.05 ; \mathrm{DM}$ yields $=$ Dry matter yields; $\mathrm{CP}$ yields $=$ Crude protein yields; $\mathrm{RFV}=$ Relative feed value; $\mathrm{SEM}=$ Standard error of the mean.

method. All statistical procedures were performed using the statistical packages for the social sciences (SPSS 17.0 for Windows; SPSS Inc., Chicago, IL, USA).

\section{RESULTS}

\section{DM and CP yields of wheat at different growth stages}

The DM yields at the flowering, milk and dough stages were 4.67, 7.59 and $7.73 \mathrm{t} / \mathrm{ha}$, respectively, and they were significantly higher at milk and dough stages than that at the flowering stage $(\mathrm{p}<0.05)$. The highest CP yields of whole crop wheat were obtained at the milk stage $(0.71 \mathrm{t} / \mathrm{ha}$ DM), which was significantly higher than those at the flowering and dough stages (0.51 and 0.50 t/ha DM, respectively) $(\mathrm{p}<0.05)$ (Table 1$)$.

\section{Chemical and microbial compositions of wheat prior to ensiling}

The DM content significantly increased with maturity $(\mathrm{p}<0.05)$ in wheat and it was near $60 \%$ at the dough stage (Table 2). The CP content in wheat decreased as maturity

\begin{tabular}{|c|c|c|c|c|}
\hline Items & Flowering stage & Milk stage & Dough stage & SEM \\
\hline Dry matter (DM, g/kg FM) & $212.3^{\mathrm{c}}$ & $339.8^{b}$ & $594.7^{\mathrm{a}}$ & 4.69 \\
\hline Crude protein (g/kg DM) & $110.3^{\mathrm{a}}$ & $93.1^{b}$ & $65.1^{\mathrm{c}}$ & 2.40 \\
\hline Ether extract (g/kg DM) & 28.1 & 33.0 & 30.4 & 1.98 \\
\hline Crude fiber (g/kg DM) & $341.6^{\mathrm{a}}$ & $186.7^{\mathrm{c}}$ & $236.6^{\mathrm{b}}$ & 9.40 \\
\hline Crude ash (g/kg DM) & $69.3^{\mathrm{a}}$ & $43.4^{\mathrm{b}}$ & $44.2^{\mathrm{b}}$ & 3.54 \\
\hline $\mathrm{NFE}(\mathrm{g} / \mathrm{kg} \mathrm{DM})$ & $450.8^{c}$ & $643.8^{\mathrm{a}}$ & $623.7^{b}$ & 4.98 \\
\hline NDF (g/kg DM) & $625.2^{\mathrm{a}}$ & $501.9^{\mathrm{b}}$ & $598.8^{\mathrm{a}}$ & 11.76 \\
\hline $\mathrm{ADF}(\mathrm{g} / \mathrm{kg} \mathrm{DM})$ & $334.3^{\mathrm{a}}$ & $229.9^{b}$ & $293.8^{\mathrm{a}}$ & 13.81 \\
\hline WSC (g/kg DM) & $133.4^{\mathrm{b}}$ & $177.3^{\mathrm{a}}$ & $38.9^{c}$ & 4.61 \\
\hline $\mathrm{pH}$ & $6.65^{\mathrm{a}}$ & $5.35^{\mathrm{c}}$ & $5.71^{b}$ & 0.07 \\
\hline Buffering capacity (mE/kg DM) & $192.7^{\mathrm{a}}$ & $109.5^{b}$ & $52.3^{\mathrm{c}}$ & 8.25 \\
\hline Lactic acid bacteria (lg cfu/g FM) & $4.6^{\mathrm{a}}$ & $3.4^{\mathrm{b}}$ & $4.1^{\mathrm{ab}}$ & 0.34 \\
\hline Aerobic bacteria (lg cfu/g FM) & $7.0^{\mathrm{b}}$ & $7.0^{\mathrm{b}}$ & $9.0^{\mathrm{a}}$ & 0.33 \\
\hline Yeast (lg cfu/g FM) & 5.3 & 5.3 & 5.6 & 0.24 \\
\hline Mold (lg cfu/g FM) & 4.7 & 4.4 & 4.8 & 0.17 \\
\hline
\end{tabular}

Table 2. The chemical and microorganism composition of wheat harvested at different stages prior to ensiling

FM = Fresh matter; NFE = Nitrogen free extract; NDF = Neutral detergent fiber; ADF = Acid detergent fiber; WSC = Water-soluble carbohydrates; $\lg =$ Denary logarithm of the numbers; cfu = Colony-forming units; SEM = Standard error of the mean. Values within the same row with different letters differ significantly from each other at $\mathrm{p}<0.05$. 
Table 3. Effects of maturity stage and LAB inoculants on the fermentation quality of wheat silage

\begin{tabular}{|c|c|c|c|c|c|c|c|c|}
\hline \multirow{2}{*}{$\begin{array}{l}\text { Maturity } \\
\text { stage }\end{array}$} & \multirow{2}{*}{ LAB } & \multirow{2}{*}{$\mathrm{pH}$} & \multicolumn{4}{|c|}{ Organic acids (g/kg DM) } & \multirow{2}{*}{$\begin{array}{c}\mathrm{NH}_{3}-\mathrm{N} \\
(\mathrm{g} / \mathrm{kg} \mathrm{TN})\end{array}$} & \multirow{2}{*}{$V$-score } \\
\hline & & & Lactic & Acetic & Propionic & Butyric & & \\
\hline \multirow[t]{3}{*}{ Flowering } & Control & $3.88^{\mathrm{de}}$ & $100.3^{\mathrm{b}}$ & $18.8^{\mathrm{de}}$ & $4.3^{\mathrm{cdef}}$ & $0.2^{\mathrm{ab}}$ & $138.4^{\mathrm{a}}$ & $72.03^{\mathrm{c}}$ \\
\hline & LAB 1 & $3.54^{\mathrm{g}}$ & $120.5^{\mathrm{a}}$ & $22.6^{\mathrm{d}}$ & $3.0^{\mathrm{def}}$ & $0.5^{\mathrm{a}}$ & $60.0^{\mathrm{c}}$ & $94.42^{\mathrm{a}}$ \\
\hline & LAB2 & $3.98^{\mathrm{d}}$ & $56.8^{\mathrm{c}}$ & $88.6^{\mathrm{a}}$ & $0.0^{\mathrm{f}}$ & $0.1^{\mathrm{b}}$ & $95.6^{\mathrm{b}}$ & $80.65^{\mathrm{b}}$ \\
\hline \multirow[t]{3}{*}{ Milk } & Control & $4.15^{\mathrm{c}}$ & $87.0^{\mathrm{b}}$ & $19.5^{\mathrm{de}}$ & $12.7^{\mathrm{abc}}$ & $0.0^{\mathrm{b}}$ & $130.8^{\mathrm{a}}$ & $72.15^{\mathrm{c}}$ \\
\hline & LAB 1 & $3.67^{\mathrm{f}}$ & $99.4^{\mathrm{b}}$ & $35.3^{\mathrm{c}}$ & $2.5^{\mathrm{ef}}$ & $0.4^{\mathrm{ab}}$ & $50.1^{\mathrm{d}}$ & $90.52^{\mathrm{a}}$ \\
\hline & LAB2 & $4.17^{\mathrm{bc}}$ & $30.9^{\mathrm{d}}$ & $70.9^{b}$ & $19.7^{\mathrm{a}}$ & $0.3^{\mathrm{ab}}$ & $94.0^{\mathrm{b}}$ & $80.39^{b}$ \\
\hline \multirow[t]{3}{*}{ Dough } & Control & $4.24^{\mathrm{ab}}$ & $22.4^{\mathrm{de}}$ & $12.0^{\mathrm{ef}}$ & $11.4^{\mathrm{abcd}}$ & $0.0^{\mathrm{b}}$ & $49.8^{\mathrm{d}}$ & $92.43^{\mathrm{a}}$ \\
\hline & LAB 1 & $4.12^{\mathrm{cd}}$ & $36.2^{\mathrm{d}}$ & $6.5^{\mathrm{f}}$ & $15.6^{\mathrm{ab}}$ & $0.0^{\mathrm{b}}$ & $40.1^{\mathrm{e}}$ & $92.34^{\mathrm{a}}$ \\
\hline & LAB2 & $4.30^{\mathrm{a}}$ & $7.8^{\mathrm{e}}$ & $16.1^{\text {de }}$ & $10.1^{\text {bcde }}$ & $0.0^{\mathrm{b}}$ & $40.5^{\mathrm{e}}$ & $91.32^{\mathrm{a}}$ \\
\hline SEM & & 0.02 & 3.28 & 2.97 & 2.68 & 0.11 & 2.94 & 1.29 \\
\hline \multirow[t]{3}{*}{ Significance } & Stage & $* *$ & $* *$ & $* *$ & $* *$ & $* *$ & $* *$ & $* *$ \\
\hline & LAB & $* *$ & $* *$ & $* *$ & NS & NS & $* *$ & $* *$ \\
\hline & Interaction & $* *$ & * & $* *$ & $* *$ & NS & $* *$ & $* *$ \\
\hline
\end{tabular}

Values within the same column with different letters differ significantly from each other $(\mathrm{p}<0.05)$.

*, ** Significant at $\mathrm{p}<0.05$ and 0.01 ; NS = Not significant; LAB = Lactic acid bacteria; $\mathrm{SEM}=$ Standard error of the mean; TN = Total nitrogen.

proceeded from flowering to dough stage. Fresh wheat at the milk stage had the highest WSC content, then declining sharply and reached its lowest value at the dough stage. The buffering capacity decreased with maturity. The contents of crude fiber, NDF and ADF were significantly lower in wheat at the milk stage than that at the flowering and dough stage $(\mathrm{p}<0.05)$. Therefore, whole crop wheat had higher RFV at the milk stage (131.56) as compared with the flowering (93.60) and dough stages (102.88) $(\mathrm{p}<0.05)$ (Table 1). All the materials had LAB less than $10^{5} \mathrm{cfu} / \mathrm{g}$ FM.

\section{Fermentation quality of wheat silage}

Growth stage and LAB inoculation had significant effects on all the parameters of $\mathrm{pH}$, lactic acid, acetic acid and $\mathrm{NH}_{3}-\mathrm{N}$ contents $(\mathrm{p}<0.01)$, whereas their interaction had no significant effects on butyric acid contents $(p>0.05)$ (Table 3). As wheat matured from flowering to dough stage, its silage without LAB inoculants tended to have higher $\mathrm{pH}$ values and lower contents of lactic acid and $\mathrm{NH}_{3}-\mathrm{N}$. LAB1 inoculation significantly reduced $\mathrm{pH}$ values and $\mathrm{NH}_{3}-\mathrm{N}$ content at all three maturation stages compared with their corresponding controls, and markedly increased lactic acid content in wheat silage of the flowering and milk stages $(p<0.05)$. LAB2 inoculation significantly decreased lactic acid and $\mathrm{NH}_{3}-\mathrm{N}$ content $(\mathrm{p}<0.05)$, while it had no significant effect on $\mathrm{pH}$ values $(\mathrm{p}>0.05)$. In addition, wheat silage at the dough stage had no butyric acid and less $\mathrm{NH}_{3-}$ $\mathrm{N}$ content than that at flowering and milk stages $(\mathrm{p}<0.05)$ At the dough stage, all the silages had $V$-scores higher than 90. While at the flowering and milk stages, only the silages inoculated with LAB1 had $V$-scores higher than 90, the $V$-scores of control and LAB2 inoculated silages were about 72 and 80 , respectively.

\section{Aerobic stability of wheat silage}

When the silages were exposed to the air for $192 \mathrm{~h}$, all the LAB2 inoculated silages were stable as indicated by less $\mathrm{pH}$ changes, irrespective of maturity stage. While the $\mathrm{pH}$ in control and LAB1 inoculated silages began to rise within $144 \mathrm{~h}$, especially for the LAB 1 inoculated silages whose $\mathrm{pH}$ values exceeded 5.5 within $48 \mathrm{~h}$ for wheat at the flowering and milk stages (Figure 1). Therefore, the aerobic stability of wheat silage was in the order: dough stage $>$ milk stage>flowering stage, and LAB2 inoculating improved the aerobic stability, while LAB1 inoculating promoted aerobic deterioration when compared to the control.

\section{DISCUSSION}

Whole crop wheat is a good forage crop to ensile in many parts of the world, whereas its nutritive value and silage quality depend much upon the maturation stage. In the present study, the DM content and DM yields of wheat increased with maturity, reaching the highest value at the dough stage, which could be attributed to the increasing ratio of grain to biomass in wheat at the dough stage. Ashbell et al. (1997) studied the changes in yields of whole crop wheat in Israel; their results showed that the increase in DM yields from milk to dough stage was approximately $40 \%$. However, there was no significant difference in DM yields between the milk and dough stage in this study, which might owe to the difference of climatic conditions and wheat cultivar. The nutritive characteristics of whole crop wheat markedly differed from the flowering to the dough stage in the current experiment. CP content in wheat declined gradually with the delay of harvest time due to protein synthesis being inhibited by the weak 

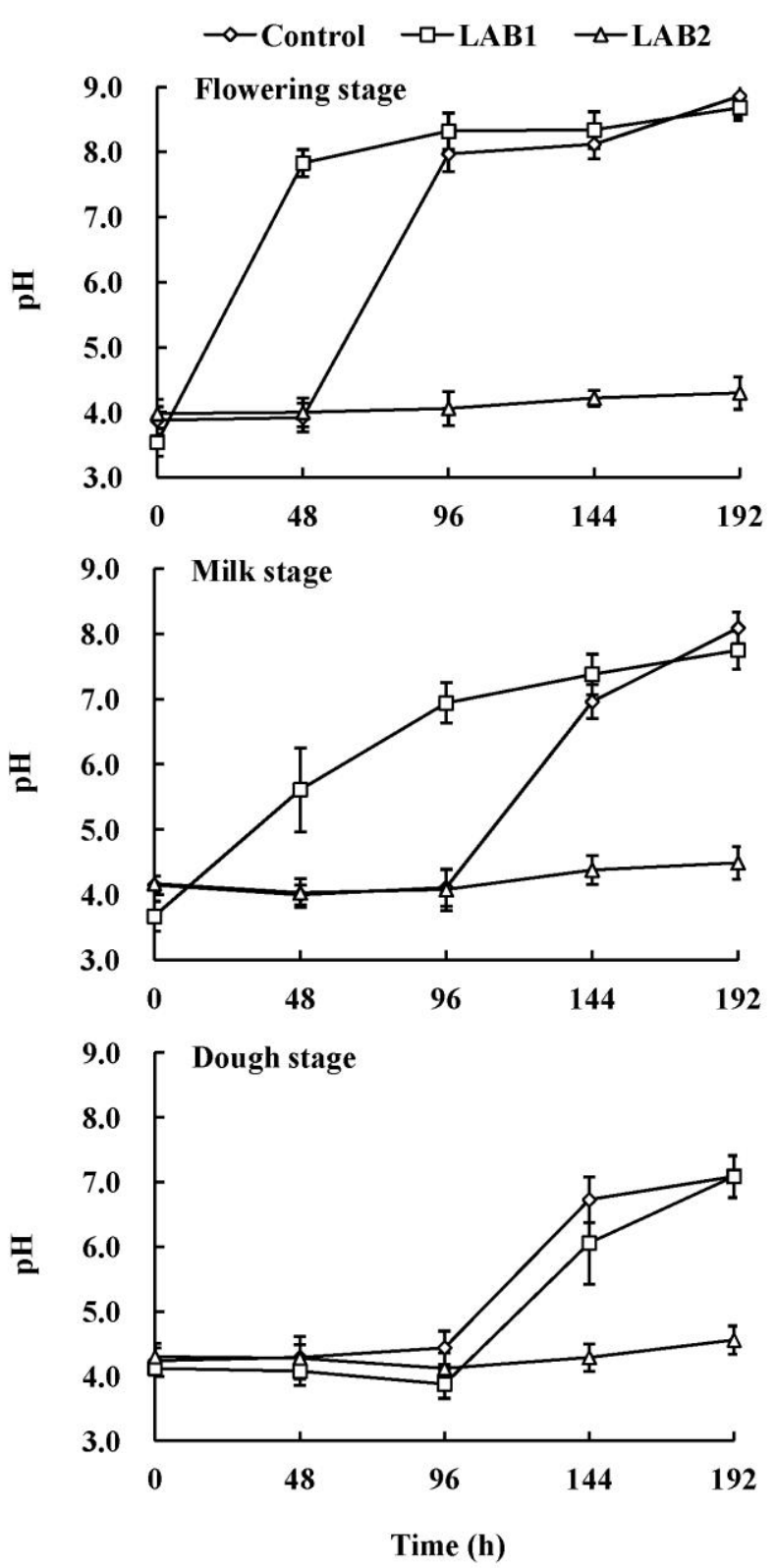

Figure 1. $\mathrm{pH}$ changes in wheat silages after exposed to the air. $\mathrm{LAB}=$ Lactic acid bacteria. Values are means and standard deviation represented by vertical bars.

photosynthesis at the more mature stage (Throop, 2005). The WSC content of wheat was the highest at the milk stage and decreased sharply at the dough stage as a result of starch accumulation in the grain with the increasing maturity. Similar results were shown in the study of Filya (2003b).

Maturity stage also has a great influence on the fermentation quality of wheat silage. The moisture content of crop, affected by growth time, is one of the important factors influencing silage fermentation quality and should be $60 \%$ to $70 \%$ for silage making. A lower DM content, such as in the early stage of maturity, is associated with butyric acid fermentation and large volumes of effluent containing valuable highly digestible nutrients. On the contrary, a higher DM content will restrict compaction and fermentation, causing deterioration of silages and nutrient loss (Muck et al., 1997; Wan et al., 2007). In the present study, lactic acid content decreased markedly from the flowering to dough stage, this might be attributed to the decreasing moisture content with maturity. However, lactic acid production in wheat silage was still sufficient to assure silage with high fermentation quality at the dough stage, though WSC content in wheat at this stage was low. Hydrolysis of starch in the wheat grains by endogenous amylases could be the substrate for silage fermentation at the dough stage (Filya, 2003b).

Of the various factors influencing silage fermentation quality of forage crops, LAB and WSC are two critical ones and often limit desirable fermentation when they are insufficient (Zhang, 2002). However, the epiphytic LAB present in the crop are insufficient in most cases and many of them reproduce slowly in the early stage of ensiling, leading to undesirable fermentation quality. LAB inoculants, mainly homofermentative Lactobacilli, are often used as silage additives to stimulate lactic acid fermentation, reducing $\mathrm{pH}$ and thus inhibiting undesirable microorganisms and protein hydrolysis of silages (Ohyama et al., 1977; Gordon, 1992; Kung et al., 2001). This trend was shown in the present experiment with whole crop wheat adding with LAB1 inoculant, especially in silages harvested at flowering and milk stage. Inoculating LAB2, a heterofermentative strain, reduced lactic acid content and notably increased acetic acid content, but had no significant effect on the $\mathrm{pH}$ values compared to the control silages.

When the silo is opened, the anaerobic environment is changed to an aerobic one and microorganisms which remain dormant in the absence of air multiply, resulting in a deterioration of silages, especially in warm climates (Woolford, 1990; Ashbell et al., 2002). Many workers have found that aerobic deterioration resulted from the activity of aerobic bacteria, yeast and mold utilizing residue WSC and lactic acid producing a rising $\mathrm{pH}$ and energy loss and even the possibility of producing harmful by products (Honig et al., 1980; MuDonald et al., 1991; Weinberg et al., 2003). Therefore, less $\mathrm{pH}$ change indicates good aerobic stability of silage. In the current study, LAB1 inoculating promoted $\mathrm{pH}$ increase to some extent during the exposure to the air, while LAB2 inoculated silages were of good stability during the experimental period of $192 \mathrm{~h}$. Weinberg et al. (1993a) showed that homofermentative LAB enhanced silage aerobic spoilage for lacking of short-chain VFAs. Furthermore, amounts of lactic acid produced by such inoculants can serve as a substrate for lactate-assimilating yeasts upon aerobic exposure (Muck et al., 1997; Filya et al., 2000). LAB2, a heterofermentative inoculant, produced much acetic acid in the present study, which had a strong 
antifungal ability. Oude Elferink et al. (2001) and Nussio (2005) reported that silage containing much acetic, butyric and other volatile fatty acids was of good aerobic stability, as such organic acids could inhibit the development of yeasts and moulds.

\section{CONCLUSIONS}

Whole crop wheat as forage should be harvested at the milk stage to gain the highest $\mathrm{CP}$ yields and relative feed value, and the lowest contents of crude fiber, NDF and ADF. Although whole crop wheat at the dough stage had the best fermentation quality for silage, its nutrient composition was obviously inferior to that at the milk stage. Inoculating LAB1 significantly reduced the $\mathrm{pH}$ value and $\mathrm{NH}_{3}-\mathrm{N}$ content, while inoculating LAB2 improved the aerobic stability of wheat silages at the different maturity stages.

\section{ACKNOWLEDGEMENTS}

This work was supported by National Key Technology R\&D Program for the 12th Five-year Plan (2011BAD17B02) and the Earmarked Fund for Modern Agro-industry Technology Research System, China. The authors would like to thank Prof. Lin Zhang for providing the wheat seed.

\section{REFERENCES}

Adamson, A. H. and A. Reeve. 1992. Nutritional evaluation of whole-crop wheat. In: Whole-Crop Cereals (Ed. B. A. Stark and J. M. Wilkinson). Chalcombe Publications, Aberystwyth, UK. pp. 85-96.

Arieli, A. and G. Adin. 1994. Effect of wheat silage maturity on digestion and milk yield in dairy cows. J. Dairy Sci. 76:237243.

Ashbell, G. and D. Sklan. 1985. Winter wheat for silage: a doublecropping system for use in subtropical climate. Feedstuffs 57: 18-19.

Ashbell, G., Z. C. Weinberg, I. Bruckental, K. Tabori and N. Sharet. 1997. Wheat silage: effect of cultivar and stage on yield and degradability in situ. J. Agric. Food Chem. 45:709712.

Ashbell, G., Z. C. Weinberg, Y. Hen and I. Filya. 2002. The effects of temperature on the aerobic stability of wheat and corn silages. J. Ind. Microbiol. Biotechnol. 28:261-263.

Association of Self-supply Feed Evaluation. 2001. Guide book for forage evaluation. Japan Grassland Agriculture and Forage Seed Association, Tokyo. pp. 93-96.

AOAC. 1990. Official methods of analysis. 15th ed. Association of Official Analytical Chemistry, Arlington, VA, USA.

Filya, I., G. Ashbell, Y. Hen and Z. G. Weinberg. 2000. The effect of bacteria inoculants on fermentation and aerobic stability of whole crop wheat silage. Anim. Feed Sci. Technol. 88:39-46.

Filya, I. 2003b. Nutritive value of whole crop wheat silage harvested at three stages of maturity. Anim. Feed Sci. Technol. 103:85-95.

Gordon, F. J. 1992. Improving the feeding value of silage through biological control. In: Proceedings of the All-tech European LectureTour, Birmingham, Alltech UK. pp. 2-17.

Henderson, A. R., D. R. Seale, D. H. Anderson and S. J. E. Heron. 1990. The effect of formic acid and bacterial inoculants on the fermentation and nutritive value of perennial ryegrass silage. In: Proceeding of Eurobac Conference (Ed. S. Lindgren and K. L. Petterson). Swedish University of Agricultural Sciences, Uppsala, Sweden, August 1986. pp. 93-98.

Honig, H. and M. K. Woolford. 1980. Changes in silage on exposure to air. Occasional Symposium of the British Grassland Society 11:76-87.

Kung, L. J. R. and N. K. Ranjit. 2001. The effect of Lactobacillus buchneri and other additives on fermentation and aerobic stability of barley silage. J. Dairy Sci. 84:1149-1155.

McDonald, P., A. R. Henderson and S. J. Heron. 1991. Microorganisms. In: The Biochemistry of Silage, 2nd Ed (Ed. P. McDonald, A. R. Henderson and S. J. Heron). Chalcombe Publications, Aberystwyth. pp. 81-151.

Muck, R. E. and L. J. R. Kung. 1997. Effects of silage additives ensiling. In: Silage: Field to Feedbunk (Ed. R. E. Muck and L. J. R. Kung). NRAES-99, NRAES, Ithaca, NY, USA. pp. 187199.

Murphy, R. P. 1958. A method for the extraction of plant samples and the determination of total soluble carbohydrates. J. Sci. Food Agric. 9:714-717.

Novozamsky, I., E. R. Van, J. C. Van Schouwenburg and I. Walinga. 1974. Total nitrogen determination in plant material by means of the indophenol-blue method. Neth. J. Agric. Sci. 22:3-5.

Nussio, L. G. 2005. Silage production from tropical forages. In: Proceedings of the XIVth International Silage Conference, a satellite workshop of the XXth International Grassland Congress, Belfast, Northern Ireland. pp. 97-107.

Ohyama, Y., S. Hara and S. Masaki. 1977. The use of caproic acid to prevent aerobic deterioration of silage after opening, with special reference of the amounts and time of application. J. Sci. Food Agric. 28:369-374.

Oude Elferink, S. J. W. H., J. Krooneman, J. C. Gottschal, S. F. Spoelstra, F. Faber and F. Driehuis. 2001. Anaerobic conversion of lactic acid to acetic acid and 1,2 - propanediol by Lactobacillus buchneri. Appl. Environ. Microbiol. 67:125132.

Playne, M. J. and P. McDonald. 1966. The buffering constituents of herbage and of silage. J. Sci. Food Agric. 17:264-268.

Rohweder, D. A., R. F. Barnes and N. Jorgensen. 1978. Proposed hay grading standards based on laboratory analyses for evaluating quality. J. Anim. Sci. 47:747-759.

Spoelstra, S. F. 1991. Chemical and biological additives in forage conservation. In: Proceedings of the Conference on Forage Conservation Towards 2000 (Ed. G. Pahlow and H. Honig). Institute of Grassland and Forage Research, Braunschweig, Germany. pp. 48-70.

Throop, H. L. 2005. Nitrogen deposition and herbivory affect biomass production and allocation in an annual plant. OIKOS. 111:91-100. 
Van Soest, P. J., J. B. Robertsom and B. A. Lewis. 1991. Methods for dietary fiber, neutral detergent fiber and non-starch polysaccharides in relation to animal nutrition. J. Dairy Sci. 74:3583-3597.

Wan, L. Q., X. L. Li, X. P. Zhang and F. He. 2007. The effect of different water contents and additive mixtures on Medicago sativa silage. Acta Pratacul. Sin. 2:40-45.

Weinberg, Z. G., G. Ashbell and A. Azrieli. 1988. The effect of applying lactic acid bacteria at ensilage on the chemical and microbiological composition of vetch, wheat, and alfalfa silages. J. Appl. Microbiol. 64:1-7.

Weinberg, Z. G., G. Ashbell, Y. Hen and Z. Harduf. 1991. Ensiling whole wheat for ruminant feeding at different stage of maturity. Anim. Feed Sci. Technol. 32:313-320.

Weinberg, Z. G., G. Ashbell, Y. Hen and A. Arieli. 1993a. The effect of applying lactic acid bacteria at ensiling on the aerobic stability of silages. J. Appl. Microbiol. 75:512-518.
Weinberg, Z. G., G. Ashbell, A. Arieli and I. Brukental. 1993b. Ensiling peas, ryegrass, and wheat with additives of lactic acid bacteria (LAB) and cell wall degrading enzymes. Grass Forage Sci. 48:70-78.

Weinberg, Z. G., R. E. Muck and P. J. Weimer. 2003. The survival of silage inoculants lactic acid bacteria in rumen fluid. J. Appl. Microbiol. 94:1066-1071.

Weinberg, Z. G., P. Khanal, C. Yildiz, Y. Chen and A. Arieli. 2010. Effects of stage of maturity at harvest, wilting and LAB inoculants on aerobic stability of wheat silages. Anim. Feed Sci. Technol. 158:29-35.

Woolford, M. K. 1990. The detrimental effects of air on silage. J. Appl. Microbiol. 68:101-116.

Zhang, J. G. 2002. Roles of biological additives in silage production and utilization. Res. Adv. Food Sci. 3:37-46.

Zhang, J. G., X. D. Liu, Z. Z. Cao, Z. Yu and Y. G. Lu. 2008. Current status and perspectives of research and utilization of forage rice. Acta Pratacul. Sin. 5:151-155. 